\title{
ARE FISCAL DEFICITS REALLY INFLATIONARY? AN INVESTIGATION INTO ETHIOPIA'S EXPERIENCE
}

\author{
Minyahil ALEMU ${ }^{1 *}$
}

\begin{abstract}
Received: August 2020 | Accepted: November 2020 | Published: December 2020
Please cite this paper as: Alemu, M. (2020) Are Fiscal Deficits Really Inflationary? An Investigation into Ethiopia's Experience, Holistica Journal of Business and Public Administration, Vol. 11, Iss. 3, pp.11-24
\end{abstract}

\begin{abstract}
This study establishes long-run relations between budget deficits and inflation, while controlling for money supply owing to the justified links between deficits and money supply especially for developing countries. We employed time series data with temporal coverage of 1980-2018. Augmented Dickey Fuller has tested nonstationary for all series, but with all stationary at first difference. The Engle-Granger (1981) methodology for Cointegration tested long-run relation between budget deficits, money supply and inflation. Due to Laney and Willet (1983), the conventional least squares regression was adopted to estimate parameters of long-run equation. The results evidenced that fiscal deficits and money supply have been at the root of galloping inflation in Ethiopia. Besides, budget deficits have been the root cause of money supply growth in Ethiopia; while giving empirical support to the hypothesis that, governments of least developed countries resort to monetize large portion of their deficits. There is a need to reform the fiscal aspect of the government, if the mounting rate of deficits has to be lessened. Budgetary imbalances can be rectified through enhancement of domestic capital market and setting limits on central bank borrowing. Besides, it could be vital to expand the tax base as well as intensify efficiency of the existing tax system in the country.
\end{abstract}

Keywords: Cointegration; Ethiopia; Fiscal Deficits; Inflation; Money Supply; Stationarity.

\section{Introduction}

This paper adds to the existing literature by providing empirical links between budget deficits, money supply and inflation, which is based on fairly large time series observation. Apart from examining the impact of deficits on inflation, we have tested the empirical validity of common views in least developed countries that, deficits are more of monetized in these countries. As a least developed country, Ethiopia is not an exception to the features of developing economies with reference to fiscal hypothesis. The country's extreme reliance on monetary financing of deficits might manifest long lasting costly inflation. Because of sustained legacy of economic commitments through budgetary

\footnotetext{
1*Corresponding author. Jimma University,Ethiopia; mineecon2008@gmail.com.
} 
growth in Ethiopia, inspecting the long run dynamics of fiscal deficits with other macroeconomic variables would be inevitable. This study employs time series of yearly data from Ethiopia to determine whether budget deficits are inflationary. The temporal coverage was from fiscal year 1980/81and 2019/20.

Monetarists demonstrate a one-to-one relationship between money and price, as clarified in the conventional Quantity Theory (Milton, 1971; Keynes, 1936; Snowdon \& Vane, 2005); where neutrality of money is a key contemplation. The Cambridge schools portrayed vibrant distinction between demand for and supply of money. Money demand is basically associated to transactions, having positive relation to aggregate money expenditure. In the national income identity, the expenditure and income approaches are interchangeable; hence, the Cambridge version of QTM for long-run money demand can begiven by the identity ( $M d=k P Y)$, where $k$ is the portion of value of national income (PY) that agents wish to hold. We should be aware here that, $\mathrm{k}$ could change in the short run (Laidler, 1993); but, in the above equation $\mathrm{k}$ is fixed. If we assume money supply is exogenous, equilibrium in the money market satisfy the condition $M=M d$. This conceptualization modifies our model as $\mathrm{M}=\mathrm{kPY}$. With $\mathrm{k}$ and $\mathrm{Y}$ constant, any change in $M$ proportionately changes $P$. A lesson could follow that; the long-run process of inflation could be understood as response to growth of money supply in the system. As long as the supply of goods and services is constrained by presumed full employment output level, disequilibrium in the goods market (Gd>Gs) gives rise to general price at a rate of initial growth in money supply (Snowdon \& Vane, 2005; Olson, 2010).

With $\mathrm{k}$ and $\mathrm{Y}$ fixed (especially in the long-run) budget deficits become an issue. We have seen above that money have no long-run effect on real variables. If so, any addition to the existing balance could only aggravate the cost of inflation. To afford livelihood at a new price, agents could resort to borrow elsewhere alternatives are there. At macro level, the same scenario could be reflected in the form of budget deficits. When money supply growth exceeds the demand for cash balances at the prevailing level of price, an excess purchasing power of goods and services in the economy could result in higher price level. Hence, budget deficits become inflationary since money supply grows in excessive rate than required to maintain the normal operation of the system. That means, central banks tend to inject more money to finance initial deficits, and this additional balance could further aggravate inflationary pressure in the system. Budget deficits, money growth and inflation oscillate with only neutral effect on real variables in the long-run (see Romer, 1993; Yamaguchi, 2013; Mankiw, 2010).

Empirically, the linkages among money supply, inflation and budget deficit remain inconclusive. In their practical work some used to evidence the causality in reverse. For example (Hoang, 2014; Abizadeh \& Yousefi, 1998; Mukhtar \& Zakaria, 2010) confirmed insignificant relation between budget deficit and inflation; while (Yemane, 2008; Minyahil et al, 2016; Yamaguchi, 2013; Nurmadihah et al, 2011; Habtamu, 2013; Rebecca, 2014; Kenneth \& Anthony, 2015) presented that high and persistent budget deficits would give rise to persistent inflation, via its initial impulse on money supply. This indicates that, the dynamics of macroeconomic variables is indeterminate despite several theoretical 
foundations with them most; thus, there is a need to have empirical updates of their behaviour across time and countries.

Budgetary imbalances can be redressed by borrowing (external or domestic) or money printing, the latter being only inflationary in the long run as explained by the QTM (Milton, 1971; Rebecca, 2014; Abate \& Rao, 2015). A country can finance its deficits through foreign borrowings, domestic borrowings (non-bank and the banking sector)and money creation. Developing countries resort to monetary financing as it is not easy for them to access external borrowing. In support of this argument, Shahin shown that, developing countries used to finance about 72.8 per cent of their deficits through money creation (see Shahin, 1992). As a result, most of the inflationary cases in these countries have reported to have monetary base. This scenario also gives farther support to the hypothesis of Classical economists, on their proposition through QTM. It is a general belief that since developing countries can't borrow as easily as developed countries, they resort more to monetize deficits.

Deficit financing is viewed inflationary when it is monetized compared to debt financing (Shahin, 1992; Saleh \& Harvie, 2005; Sargent \& Wallace, 1981). The justification for the later approach follows that, debt financing can impose only short-lived inflationary pressure if the government temporarily borrows from the central bank (domestic source) but does not repay the loan in a moment such that it could let money supply grow in unjustifiable rate and level. In short, the loan should be paid back considering the time and trend in the development of money supply, as well as the general macroeconomy. As external borrowings are usually absenter costly, developing countries tend to borrow from domestic sources especially the banking sector. We, therefore, expect budget deficit to associate positively with inflation in Ethiopia; given that deficits being more of monetized in the country. Nonetheless, there is a need to recognize the opportunity for Ethiopia to access funds from multilateral organizations like, International Monetary Fund (IMF) and the World Bank (WB), in the form of external financing. If the borrowed fund is properly utilized for the intended purpose, deficits will be less inflationary. A problem with developing countries is that, foreign borrowings are diverted towards unintended purpose and usually embezzled by the officials close to them. Consequently, these foreign borrowings serve nothing towards the national wellbeing, except their inadequate pressure on the economy in the form of income inequality, rising government debt, increasing money supply, rising inflation and decline in the welfare of the poor (Yamaguchi, 2013; Rebecca, 2014; Kenneth \& Anthony, 2015). Given that those multilateral loans to Ethiopia have been properly addressed, then we expect only part of the budget deficits to be mitigated by money creation. In this case, the relation between budget deficits and money supply couldn't be proportional. With Ethiopia's multidimensional poverty and depraved corruption profile, we however, suspect the effective use of multilateral loans; while forming one-to-one relation between deficits and money supply.

For the past ten to fifteen years growth in reserve money and budget deficits was dramatic in Ethiopia. This is due to government's commitment to rehabilitate the lagging 
economy from war and inadequate policies with previous regime (World Bank, 2004; Tadesse \& Guttormsen, 2008).Yet, relatively better economic environments for private sector participation gave rise to money velocity, and hence persistent inflation during and after the death of command system. One advantage for the coming administration could be the paused war, which has an important implication with the fiscal position whereby reducing military expenditures. However, the lost receipts from bilateral relations, particularly from Soviet Union, left fiscal position the same. For instance, gross public expenditures during 1991/92decreasedby about 24 percent; and that, the government revenue declined by around 21 percent. It is obvious that; changes in both fiscal components were almost equal with null net value. Consequently, the new government has aggressively used central bank borrowing and money creation to finance deficits; this has long been at the root of galloping inflation (Alemayehu \& Kibrom, 2008; Shibeshi, 1994; Leaning et al, 2009; Abate \& Rao, 2015; Habtamu, 2013).

Ethiopia is not an exception to the features of developing economies with reference to fiscal hypothesis. The country's extreme reliance on monetary financing of deficits, due to lacking access to foreign borrowing, might manifest long lasting costly inflation. Because of sustained legacy of economic commitments through budgetary growth in Ethiopia, examining the long run dynamics of fiscal deficits with other macroeconomic variables would be inevitable. This study employs time series of yearly data from Ethiopia to determine whether budget deficits are inflationary. The temporal coverage was from fiscal year 1980/81and 2019/20. It establishes the long run relation between budget deficit, money growth and inflation to Ethiopian context.

\section{Research Methodology}

\subsection{The Data}

The study used annual time series data for government budget deficit, money supply (M2 + quasi-money) and CPI accounted inflation. The World Bank data catalogue was our source. The temporal coverage ranges between 1980/81and2019/20. All variables were converted to natural logarithmic form for the purpose of coefficient efficiency based on (Yamaguchi, 2013; Minyahil et al., 2016; Humphrey, 1998). Therefore, the series of temporal observation totals 38 ; which is fairly sufficient to determine the long-run dynamics from a developing nation, such as, Ethiopia.

\subsection{Model Specification}

\subsubsection{The Theoretical Model}

Monetization of deficit is the practice by which a rise in government deficits could give rise to money growth, and which in turn is reflected in the form of high inflation in the long-run (Rita, 2012; Keynes, 1936; Milton, 1971; Shahin, 1992). Fiscal shortfalls may cause money creation following political pressures to mitigate government financing gaps, which is hypothesized to be common across less developed countries. 
Literatures contend that, there are often political pressures in favour of money creation to financing deficits on the part of the monetary policy across developing countries. Central banks (government banker) operate to the will of the government, and are tremendously responsive to the political demands of monetizing deficits. Government policy affects monetary policy when monetary policy makers respond to an increase in the rate of interest following an initial upswing in government central bank borrowing. For interest rate targeting, monetary policy tends to raise money growth buying government securities. Moreover, fiscal deficits can influence money supply if countries borrow from abroad making the international element of high-powered money high, which in turn, raises the monetary base without comprehensive sterilization (Haan \& Zelhorst, 1990; Shahin, 1992; Kenneth \& Anthony, 2015; Humphrey, 1998; Minyahil et al., 2016). Fiscal policy may also influence monetary policy because of time inconsistency problem monetary authorities could face; i.e., if interest rate (nominal) on government debt is fixed, authorities will have an incentive to produce an unanticipated inflation. This has an important implication to the government, capital gain by the government following reductions in the real value of debt. Note however that, this helps only if the government debt is denominated in domestic currency (Ibid).Shahin (1992) links budget deficits to inflation in two important channels. He motivated his demonstration based on the classical hypothesis that inflation is largely resulted from fiscal incompetence leading to monetization of deficits. Besides, he explained in relation to the BOP, in which deficits are believed to cause deficits in current account balance farther causing shocks in the exchange rate. The later event appears to depress the value of domestic currency whereby leading to high inflationary expectation. Inflation would occur as a result. This study, however, uses the first hypothesis linking budget deficits to inflation through money growth as it would be particular to developing countries.

\subsubsection{An Empirical Model}

Based on the above theoretical foundation, this study adopts an empirical model to establish the long run relations between budget deficits, money supply and inflation from Ethiopia. Following (Rita, 2012; Laney \& Willet, 1983; Niskanen, 1978; Egwaikhide et al., 1994) the below long-run model has been adopted in this study. A major improvement rests on the extension of the number of observations and variables definition. Uncommon with them all, CPI accounted inflation was taken in the current analysis. Besides, our definition of money supply was extended to include quasi-money capturing the effect of actually circulating balance. The relationship is specified as follows:

$I N F_{t}=\beta_{0}+\beta_{i} \sum_{i=1}^{n} M_{t-i}+\beta_{j} \sum_{j=1}^{n} B D_{t-j}+u_{t}$

Where INF stands for inflation rate measured as annual percentage change in Consumer Price Index, MS represents money supply (broad and quasi money); and BD is budget deficit. Ut is white noise error term normally independently and identically distributed; $u_{t} \sim \operatorname{IID}(0, \sigma 2)$. 


\subsection{The Unit-Root Test}

The unit root properties of individual series were examined using the Augmented DickeyFuller (ADF) approach (Dickey and Fuller, 1979). ADF requires regressing the first difference of the response variable $\left(\Delta \mathrm{Y}_{\mathrm{t}}\right)$ on a constant, a time trend $\left(\mathrm{Y}_{\mathrm{t}-1}\right)$ and lags of the dependent variable, specified as follows:

$\Delta \mathrm{Y}_{\mathrm{t}}=\alpha_{0}+\gamma \mathrm{t}+\delta \mathrm{Y}_{\mathrm{t}-1}+\sum_{\mathrm{i}=1}^{\mathrm{k}} \lambda_{\mathrm{i}} \Delta \mathrm{Y}_{\mathrm{t}-\mathrm{i}}+\varepsilon_{\mathrm{t}}$

Where $\Delta$ is first difference operator; $\alpha 0$ is a constant; $\gamma$ represents trend coefficient; $t$ stands for time/trend term; and $\mathrm{k}$ are the lag size. Null hypothesis is, $\mathrm{H} 0$ : ? $=0$. Rejection of the null implies that, a time series under consideration contains a unit root problem. The ADF test is based on the t-ratio of the Yt-1. If it exceeds the ADF critical at any one of the three benchmarks ( $1 \%, 5 \%$ or $10 \%)$, hence the null will be rejected, and $Y t$ is said to be stationary. Nevertheless, if $\mathrm{Yt}$ is tested non-stationary, the first difference $\Delta \mathrm{Yt}$ should then be tested for stationarity using the same procedure; and the procedure will continue until it is stationary. But, in most of the cases economic and financial data are stationary at first differences. The size of $k$ is often determined empirically, to take sufficient size so that the error term is indeed serially uncorrelated such that we obtain unbiased estimate of $\delta$ ). The appropriate lag is set, for instance, based on minimizing Akaike Information Criterion (see Gujarati, 2004; Wooldridge, 2013; Maddala, 1992).

\subsection{The Cointegration Test}

As long as the monetarists' demonstration focuses on the long-term, we first need to examine whether the variables exhibit long-run equilibrium stable relationship. If no cointegration is tested in advance, the analysis must break with no need of moving ahead. For cointegration purpose, the Engle-Granger (1987) method was employed to test a null of no cointegration, against the alternative. The null hypothesis depicts that, the OLS residual obtained from level form regression contains a unit root, examined through ADF test. If the null hypothesis is true, then the variables couldn't exhibit common long-run path. Thus, we conclude the series are not cointegrated. Engle-Granger examines if residuals of the equilibrium relationship are stationary. Details for this approach can be understood using the below static model:

$Y_{t}=\beta_{0}+\beta_{1} X_{t}+\varepsilon_{t}$

A primary requirement with $E G$ method is all variables integrated of order one; $Y_{t}, X_{t} \sim 1(1)$. Given this condition is satisfied, we run OLS regression using equation (3) to obtain OLS residuals. We, then, run ADF regression on the residual at level to determine if it is stationary. If the residual is non-stationary, conclude that there is no cointegration between the dependent and independent variables (Engle-Granger, 1987; Gujarati, 2004). Note that, Stata statistical software package version 14 was used for every regression analysis throughout this study. 


\section{Analysis Results and Discussion}

\subsection{Stationary Test Results}

Inflation, money supply and the fiscal deficit variables were all subjected to ADF unit root test to determine if they are stationary at level. The AIC minimizing lag for three of the individual series was suggested one. In none of the three level cases is the null hypothesis rejected, while the first differenced terms revealed stationarity.

Table 1 The ADF Stationarity Test Results: Temporal coverage(1980-2018)

\begin{tabular}{|c|c|c|c|c|c|c|c|c|c|}
\hline \multicolumn{5}{|c|}{ Level Form } & \multicolumn{5}{|c|}{ First Difference } \\
\hline \multicolumn{5}{|c|}{ Critical at: } & \multicolumn{5}{|c|}{ Critical at: } \\
\hline Variable & t-stat. & 0.001 & 0.005 & 0.1 & Variable & t-stat. & 0.001 & 0.005 & 0.1 \\
\hline $\ln \mid \mathrm{NF}_{\mathrm{t}-1}$ & 1.562 & -3.668 & -2.966 & -2.616 & $\Delta / n \mid N F_{t-1}$ & $-4.839 * *$ & -3.675 & -2.969 & -2.617 \\
\hline $\ln \mathrm{MS}_{\mathrm{t}-1}$ & -2.017 & -3.675 & -2.969 & -2.617 & $\Delta / n \mathrm{MS}_{\mathrm{t}-1}$ & $-6.732 * *$ & -3.682 & -2.972 & -2.618 \\
\hline $\ln \mathrm{BD}_{\mathrm{t}-1}$ & 1.065 & -3.668 & -2.966 & -2.616 & $\Delta / n \mathrm{BD}_{\mathrm{t}-1}$ & $-4.680^{* *}$ & -3.675 & -2.969 & -2.617 \\
\hline
\end{tabular}

Source: Own Computation using Stata 14, 2020

Evident from table (1) is all series with unit root problem in level form, demonstrating difference stationarity with first order. Hence, all are integrated of order one, hence EG method.

\subsection{Engle-Granger Cointegration Test Result}

After examining unit root properties, the EG approach for cointegration was used to test the null of no cointegration. The ADF test was again employed to examine the unit root property of residuals obtained from estimation of conventional LS model in level form. As discussed so far, stationarity in the residuals will reject the null hypothesis.

Table 2 Engle-Granger(1987) Cointegration Test for OLS Residuals

\begin{tabular}{lccccc}
\hline \multicolumn{5}{c}{ Critical value at: } \\
\hline Variable & t-stat. & 0.01 & 0.05 & 0.1 & Decision \\
$\Delta \mathrm{ECT}_{\mathrm{t}-1}$ & $-7.666^{* * *}$ & -3.675 & -2.969 & -2.617 & Reject the null hypothesis \\
Dependent variable: $\Delta \mathrm{ECT}_{\mathrm{t}}$ & & & \\
Null hypothesis: $\mathrm{ECT}$ is nonstationary \\
$* * *$ Rejection of the null at 1 per cent significance level
\end{tabular}

Source: Own Computation using Stata 14, 2020 
Evident from table above is significant $t$-stat of the ECM, rejecting the null hypothesis of no cointegration at 1 per cent. Hence, there is evidence for the existence of cointegrating equation among the series under consideration. Inflation, money supply and budget deficit variables of Ethiopia have stable and long-term equilibrium relationship.

Now it's time to modify our basic model (equation 1 ) since the variables are all nonstationary; i.e., since they have unit root problem in the level form. In contrast, the specification in equation (1) is in level form, which is subject to the problem of spurious regression. Thus, equation (1) is remodelled in first difference as follows:

$\Delta \ln \operatorname{lnf}_{\mathrm{t}}=\beta_{0}+\beta_{\mathrm{i}} \sum_{\mathrm{i}=1}^{\mathrm{n}} \Delta \operatorname{lnMS}_{\mathrm{t}-\mathrm{i}}+\beta_{\mathrm{j}} \sum_{\mathrm{j}=1}^{\mathrm{n}} \Delta \ln B D_{\mathrm{t}-\mathrm{j}}+\beta_{3} \mathrm{ECT}_{\mathrm{t}-1}+\mathrm{u}_{\mathrm{t}}$.

ECT stands for error correction term, whereas $u_{t}$ is the residual. Note that, an auxiliary EC term in equation (4) is due to the evidence of cointegration among the series. Evidence from table (2) reveals the variables are cointegrated at 1 per cent level of significance; consequently, the use of error correction term.

\subsection{Evidence from the Long-Run Model}

The conventional least squares method was employed to determine if budget deficits in Ethiopia is inflationary, while controlling for the effect of money supply. The validity and reliability of issues were addressed in line with OLS assumptions, and none has failed the pass test. Residuals normality, homoscedasticity, residual independence, omitted variables bias and multicollinearity issues were satisfied with individual test. After passing through the necessary pre-estimation examinations, OLS was directly estimated with all variables differenced once. Table (3) below reports the result:

Table 3 The Long-run Regression Result (1980-2018)

\begin{tabular}{cccc}
\hline Regressors & Coef. & Std. Error & t-stat. \\
\hline$\Delta \mathrm{InINF}_{\mathrm{t}-1}$ & -0.1890 & 0.0667 & $-2.83^{* * *}$ \\
$\Delta \mathrm{InMS}_{\mathrm{t}-1}$ & 0.5857 & 0.0416 & $14.06^{* * *}$ \\
$\Delta \mathrm{InBD}_{\mathrm{t}-1}$ & 0.1179 & 0.0243 & $4.85^{* * *}$ \\
$\mathrm{ECT}_{\mathrm{t}-1}$ & -0.9516 & 0.0591 & $-16.09^{* * *}$ \\
\hline
\end{tabular}

Response variable: $\Delta \ln _{\mathrm{n}} \mathrm{NF}_{\mathrm{t}}$

Null hypothesis: $\mathrm{H}_{0}: \beta_{\mathrm{j}}=0$

$F(4,33)=1798.25[0.0000]$

$\mathrm{R}^{2}=0.9954, \overline{\boldsymbol{R}}^{2}=0.9949$

Lag length (AIC): 1

$\mathrm{t}_{0.05,33}=2.042$

Obs. $=38$

*** Rejection of the null at 1 per cent level of significance

Source: Own Computation using Stata 14, 2020 
HOLISTICA Vol 11, Issue 3, 2020, pp.11-24

With all precautions noted regarding the applicability of $R^{2}$ (spurious regression and large but irrelevant regressors in the model), the reported $\left(\overline{\mathrm{R}}^{2}=0.9949\right)$ grants the strength of money supply and fiscal deficits in explaining the long-run process of inflation in Ethiopia. A unit lag used to estimate model (4) was suggested by AIC. Parameter stability test was conducted viz CUSUM and CUSUMQ, and the presence of stable relation over the sample period was confirmed. Besides, the reported probability for F-stat was significant, demonstrating an overall relevance.

In none of the cases (table3) was the null hypothesis $\left(\mathrm{H}_{0}: \beta_{\mathrm{j}}=0\right)$ accepted, while indicating the importance of all regressors in the long run process of inflation. All were reported significant at 1 per cent. A significant negative sign for ECT is suitable as required for vigorous stability of the system. An implication with the estimated coefficient of error correction term is that, there is stable equilibrium relationship between inflation, budget deficit and money supply in Ethiopia. The reported coefficient of ECT(-0.9516) indicates the speed of adjustment towards the long-term equilibrium point. Inflation adjusts about 95 percent of previous changes in money supply and budget deficit this year. Thus, a year is not sufficient to restore complete stability in the system. The remaining 5 percent will be restored back within 26 days of the next year. An interesting thing is that, the time period required for complete adjustment is short, as it takes less than 13 months.

Current inflation seems to associate inversely with previous year inflation in Ethiopia. Several arguments exist for such inflationary experience; (Alemayehu \& Kibrom, 2008; Lozano, 2008; Kenneth \& Anthony, 2015; Demeke, 2007; Kibritçioğlu, 2002; Kflindo, 1997; Hoang, 2014) explain it in relation to the role of price in determining the extent of investment. When falling prices tend to dampen production at any instance, the level of products will certainly fall the next period. Missing or incomplete information coupled with prevalent uncertainties, most commonly in food sector, investors lose their confidence. How long it takes the price falling? In LDCs, responding to this question is not such an easy task; firms in these countries become unable to predict price movement (Humphrey,1998; Kenneth \& Anthony, 2015).The cumulative effect of persistent fall in general price leads to the shortage of goods and services; hence rise in price level. Such a negative association between current and previous inflation is also subjected to agents' expectation of inflation. In this case, people consider current price collapse due to demand fall; and consequently, assume that, the government will be working towards intensifying aggregate demand. It might involve expansionary fiscal and monetary policies that could inject additional money into the system. With this expectation agents' act today in a way to protect them from higher prices tomorrow. This involves hoarding of foods stuffs and other basics, while leaving pressure on tomorrow's market and the economy at large. All this leads to price surge next period given that supply side is not responding in parallel (Loening et al., 2009; Alemayehu \& Kibrom, 2008; Hoang, 2014; Mukhtar \& Zakaria, 2010)

Neither fiscal deficits nor money supply is estimated insignificant in explaining the longrun process of inflation in Ethiopia (table 3). Besides, both series exhibited the right sign towards validating the monetarists' hypothesis to Ethiopian context. The positive 
coefficient of budget deficits manifests the government's practice to monetary financing of deficits, which as explained by QTM is extremely inflationary. The finding is consistent to notable arguments with LDCs that since with less opportunity to external borrowings, they are more likely to borrow from the central bank, and print money to finance deficits (Shahin, 1992; Yemane, 2008; Rita, 2012); and due to its obvious effect on money supply (keeping full employment output) could give rise to inflation in the long-run. Indeed, the results of the current study provide evidences that the QTM is still alive in Ethiopia. Empirically, this finding is similar to previous works by Yemane (2008) for Ethiopia; Minyahil et al. (2016) for Ethiopia; Sajid \& Riaz (2016) for Pakistan; Yamaguchi (2011) for Japan; and Hoang (2014) for Vietnam.

\subsection{Long-Run Response of Money Supply to Changes in Budget Deficits}

Conceptually, the effect of budget deficits on inflation is explained in terms of duration (time horizon) and the way it is mitigated. According to (Mishkin, 2004; Sargent \& Wallace, 1981), if government deficit is permanent and is monetized, it will give rise to high inflation. Similar argument holds that, if deficits are financed by issuing government securities (bonds and treasury) that are purchased by non-bank entities and hold them until their maturity, fiscal deficits do not give rise to money growth and inflation rates. Money is, thus, the conceived channel through which the effect of deficits transmits to inflation in the long-run. The conjectural pathway from deficits to inflation places money supply in between. Hence, we need to test whether money is a right channel to price surge following government's budgetary shortfalls. For this purpose, we have regressed money supply on budget deficits while controlling for inflation using the conventional least squares method. Below is the result:

Table 4 The Long-run Regression Result (1980-2018)

\begin{tabular}{cccc}
\hline Regressors & Coef. & Std. Error & t-stat. \\
\hline$\Delta$ InINF$_{\mathrm{t}-1}$ & 0.0466 & 0.0342 & 1.36 \\
$\Delta \mathrm{InMS}_{\mathrm{t}-1}$ & 1.0188 & 0.0509 & $20.01^{* * *}$ \\
$\Delta \mathrm{InBD}_{\mathrm{t}-1}$ & -0.0587 & 0.0783 & -0.75 \\
$\mathrm{ECT}_{\mathrm{t}-1}$ & -0.0911 & 0.0456 & $-2.00^{* *}$ \\
\hline
\end{tabular}

Response variable: $\Delta \mathrm{InMS}_{\mathrm{t}}$

Null hypothesis: $\mathrm{H}_{0}: \beta_{\mathrm{j}}=0$

$F(4,33)=3526.42[0.0000]$

$\mathrm{R}^{2}=0.9977, \overline{\boldsymbol{R}}^{2}=0.9974$

Lag length (AIC): 1

$\mathrm{t}_{0.05,33}=2.042$

Obs. $=38$

Note that, ${ }^{* * *}$ and ${ }^{* *}$, respectively, are rejection of the null at 1 and 5 percent.

Source: Own Computation using Stata 14, 2020 
The reported sign for the coefficient of the EC term is appropriate and significant, demonstrating the existence of long-run equilibrium relation in the new system. Towards validating the Sargent and Wallace (1981) hypothesis, a positive and strongly significant coefficient of budget deficits was estimated. Besides its appropriate sign, the relationship between money supply and budget deficits suggested is one-to-one. This finding provides important implication to fiscal hypothesis; the whole of budget deficits in Ethiopia have been being monetized. To be clear, the GoE has been mitigating its budgetary gaps only by borrowing from the National Bank of Ethiopia, or else by printing new currency.

The past ten years Ethiopia has been busy running the Great Renaissance Electric Dam (GRED) project, which absolutely is based on domestic funds due to the country's restricted access to international borrowings against hydro political tensions. We, thus, suspect the project has been at the root of huge budgetary discrepancies the country was experiencing. The estimated strong coefficient of budget deficit variable tells us the inadequacy in home side voluntary contribution relative to the projected cost of the GRED project. Consequently, the only practical tool for the GoE to finance the project could be to create money. The finding seems to expose the hidden, but factual, economic and financial events in the country. Hence, there is evidence for Ethiopia that, increase indeficits would give rise to inflation through its impulse on money supply. This finding gives empirical support to (Shahin, 1992) and consistent with (Minyahilet al., 2016; Keho, 2016; Yemane, 2008; Tsegay \& Rao, 2013; Sajid, 2000; Kflindo; 1997; Shibeshi, 1994; Loening et al., 2009).

\section{Summary, Conclusion and Policy Implications}

This study was aimed to establish the long-run relation between budget deficits and inflation from Ethiopian economy, while controlling for the obvious role of money supply. Money supply was visited by recognizing the theoretical implication of deficits with monetary bases of the system, more often across developing economies. The temporal coverage ranges between the fiscal years 1980/81and 2018/19. The ADF test has indicated that; money supply, inflation and budget deficits variables are all integrated of order one. The suggested order of stationarity for all has permitted the use of EngleGranger (1981) cointegration test, and that the existence of long-run relation among the variables has been confirmed too.

The conventional least squares regression was employed to establish the long-run relation among the series entered the inflation and money supply model. Several tests have supported various statistical requirements for OLS models, and the result for every assumption underlying the model was robust. There is evidence that, the long-run relation among budget deficits, money growth and inflation is strong in Ethiopia. The long-run results show strong and significant impact of previous government deficits and money supply on current inflation. The finding proves the hypothesis demonstrating the large intensity for monetary financing of deficits across developing countries; which is elucidated to surge the rate of inflation. The hypothesis could be farther trusted realizing 
the positive and strongly significant coefficient of budget deficit, where money supply was a response variable. The implication is that, a positive impulse from budget deficits to inflation transmit through the vacuum of money supply. Thus, evidence from Ethiopia validate the argument that, LDCs resort to monetize large proportion of their budgetary deficits. Consequently, the findings of this study evidence that the GoE has been mitigating its budgetary gaps by central bank borrowing or creating money.

The results of this study have important policy implications. Firstly, there is need to appreciate a large response of long-run inflation to budget deficits and money supply. Secondly, it would be important to acknowledge money supply being an important channel through which the effect of budget deficits transmits to inflation. It would be helpful to restrict the growth of money supply by tightening monetary policy towards ensuring steady growth in money supply at rate of real output. This is due to the evidence of high pressure from money supply in both dimensions; i.e., in self-contained dynamics and through its strong relation to budget deficits. Besides, there is also a need to limit government central bank borrowing to mitigate its fiscal gaps. Government reliance on central bank borrowing could be reduced by enhancing the development of domestic capital market; which is, either missing or weak in Ethiopia.

With regard to fiscal issues, it is essential to limit government's general economic intervention to reduce the expenditure side of the fiscal target. The declining share of the government could be moderated by enhancing private sector participation through various incentives; which is acknowledged for its multidimensional efficiency in the general economic system. Enhancement of the joint ventures and private investments would be wiser approach to reduce government spending. From the revenue aspect, several restructurings need to be commenced in the revenue system of the country. Expanding tax base (introducing new source of tax income), intensifying efficiency in the tax collection system (involving digitizing tax scheme, awareness creation and regular audit) and investing in business projects would help.

\section{References}

Abate, \& Rao (2015). Cointegration Analysis of Money Supply and Price in Ethiopia, Research Article, 16, no. 3: 72-79.

Abizadeh, \& Yousefi, M., (1998). Deficits and Inflation: Open Economy Model of the United States, Applied Economic Research: 107-316.

Alemayehu, G., \& Kibrom, T., (2008). The Galloping Inflation in Ethiopia: A Cautionary Tale for Aspiring Developmental States in Africa, Working Paper, Addis Ababa, Ethiopia.

Dickey, A., \& Fuller, W., (1979). Distribution of Estimators for Autoregressive Time Series with Unit Root, Journal of US Statistics: 427-431.

Engle, R., \& Granger, J., (1987). Cointegration and Error Correction Model: Representation, Estimation, and Testing, Econometrica: 251-276.

Gujarati, D., (2004). Basic Econometrics, 4th edition. New York: McGraw-Hill.

Habtamu, B., (2013). Investigation of the Causes and Dynamics Inflation in Ethiopia, Research Paper, Institute of Social Studies, the Netherlands. 
Hoang, K., (2014). Budget Deficit, Money Growth and Inflation: Evidence from Vietnam, Research Article, National Institute for Policy Studies, Vietnam.

Humphrey, T., (1998). Historical Origins of Cost-Push Fallacy, Quarterly Bulletin, Reserve Bank of Richmond, 84, no. 3: 53-74.

Keho, Y., (2016). Budget Deficits, Money Supply and Price in West Africa, Research Article, Journal of Economic \& Financial Studies, 04, no. 05: 01-08.

Kenneth, \& Anthony, (2015). Impact of Money Supply on Inflation: Evidence from ECOWAS, Research Paper, Journal of Economics and Finance, vol.6, Nnamdi Azikiwe University, Nigeria.

Keynes, J.M., (1936. The General Theory of Employment, Interest and Money. http://etext.library.adelaide.edu.au/k/keynes/john_maynard/k44g/k44g.html/.

Kilindo, A., (1997). Fiscal Operations, Money Supply and Inflation in Tanzania, AERC Research Paper 65, African Economic Research Consortium, Nairobi, Kenya.

Laney, L., \& Willet, T., (1983). Politics, Budget Deficits and the Money Supply in the United States, Public Choice Consortium, Vol. 40: 53-69.

Loening, J., Durevall, D., \& Birru, Y., (2009). Inflation Dynamics and Food Price in an Agricultural Economy: Evidence from Ethiopia', Research Paper 347.

Maddala, G., (1992). Introduction to Econometrics, 2nd edition. New York: Macmillan Publishing.

Mankiw, N.G., (2010). Macroeconomics, 7th edition. 41 Madison Avenue, USA.

Milton, F., (1971). Theoretical Framework for Monetary Analysis, Bureau of Economic Research, ISBN: 14-223-X: 15-29.

Minyahil, A., Wondaferahu, M., \& Yilkal, W., (2016). Monetary Policy and the Dynamics of Inflation in Ethiopia: An Empirical Analysis, Research Article in Economics, Journal of Human-social Science, 16, no. 4.

Mukhtar, T., \& Zakaria, M., (2010). Budget Deficit, Money Supply and Inflation: The Case of Pakistan, Research Paper, Fatima Jinnah Women University, Pakistan.

Mulat, D., Atlaw, A., Bilisuma, B., Saba, Y., \& Tadele, F., (2007). Exploring Demand and Supply Factors Behind the New Developments in Grain Prices in Ethiopia, Research Paper for DFID Ethiopia.

Nurmadihah, Jusoff, \& Asari, (2011). A VECM Approach for Explaining the Relationship between Interest Rate and Inflation towards Exchange Rate Volatility: A Case of Malaysia, Research Article, IDOSI Publications, 12, no. 2: 49-56.

Olson, (2010). Essentials of Advanced Macroeconomic Theory. Cambridge, Massachusetts

Rebecca, (2014). Fiscal Deficit, Money Growth and Inflation Dynamics in Ghana, Graduate Research Paper, Kwame Nkrumah University, Ghana.

Romer, D., (1993). Openness and Inflation: Theory and Evidence, Policy Paper, Journal of Economics, Quarterly Bulletin: 869-903.

Sajid, G., \& Riaz, B., (2016). Budget Deficit, Money Supply and Inflation: An Issue of Causality, Research Article, International Islamic University of Islamabad, Pakistan.

Shahin, W., (1992). Money Supply and Deficit Financing in Economic Development, Book Print, Greenwood Publishing Group.

Sileshi, G., (1994). Fiscal Deficits and the Monetary Sector in Ethiopia: Implications for Reform, Policy Paper, Ethiopian Journal of Economics, 3, no. 1, Addis Ababa University, Ethiopia.

Snowdon, B., \& Vane, H., (2005). Modern Macroeconomics: Its Origins, Development and Current State, Edward Elgar Publishing Inc. USA.

Tadesse, G., \& Guttormsen, A., (2008). Commodity Price Dynamics in Ethiopia: Do speculators destabilize the market?, Conference Paper, Addis Ababa, Ethiopia. 
Tsegay, M., \& Rao, M., (2015). Deficit Financing, Money Supply and Inflation in Ethiopia, Research Article in Economics, International Journal of Science and Research, ISSN (Online): 23197064.

Wooldridge, J.M., (2013). Introductory Economics: A Modern Approach, 5th edition. Michigan State University, United States.

Yamaguchi, (2013). Money and Macroeconomic Dynamics, 1st edition. Office Publications, Japan.

Yemane, W., (2008). Budget Deficits, Money and Inflation: A Case of Ethiopia, Research Article, 42, no. 1: 18-199. 